\title{
長大な跳ね出し部を有するT字 STRUCTURAL DESIGN OF A T-SHAPE 形高層建築物の構造設計 HIGHRISE BUILDING WHOSE OVER- HANGING PART IS SUPPORTED BY LONG CANTILEVER MEMBERS
}

\author{
伊藤 優 — $* 1$ 相京正巳 -2 \\ 大越俊男 - $* 3$ \\ キーワード \\ 跳ね出し，改築計画，地中連続壁，本設地盤アンカー,上下動制振，オイルダ \\ ンパー
}

\section{Keywords :}

Cantilever, Reconstruction, Wall foundation, Permanent earth anchor, Vertical anti-vibration, Oil-damper

\section{Masaru ITOH $-* 1 \quad$ Masami AlKYO $-* 2$ Toshio OKOSHI $-* 3$}

The concept of the Municipal Kawasaki Hospital reconstruction is based in continuing medical treatment activity scale and, simultaneously carrying out improvement of functions and environment as well as shortening the construction schedule.

The T-shape building was designed to overhang on top of the existing hospital. The cantilever part has 9 stories and $28.5 \mathrm{~m}$ length which is $4 / 5$ of the lower building part width.

Wall foundations and permanent earth anchors are used to solve overturning moments due to Earthquake loading. A Megastructure system supports the overhanging part. And vertical vibration is controlled with oil dampers.

\section{1.はじめに}

川崎市立川崎病院は1936年に伝染病病院として開設され，その後 総合病院となり数回の増改築が行われてきた。しかし，その施設は 老朽化が激しく，今回の改築となった。

今回の改築の基本コンセプトは，現況の病院活動規模を維小寸る ことなく医療活動を継続しながら，機能の向上と環境の改善をはか ることである。さらに当病院は川崎の中心部に位置しているため, 防災拠点としての役割も担っている。同時に工期の短維がもう 1 つ の命題であった。

このため, 建物形状は既存建屋の上にオーバーハングした T字形 の立面形状で計画された。跳ね出し部分は主用途が病室で 9 層より なり，その長さは $28.5 \mathrm{~m} て ゙ ，$ 低層部の幅の約 $4 / 5$ と長大である。

大きな跳㱛出しを持つ建築物としては，跳ね出し長さ $36 \mathrm{~m}$ を持つ 東京都立江戸博物館， $19.2 \mathrm{~m}$ の日本長期信用銀行本店などがある。 江戸博は展示室と収納庫の 2 層よりなり，展示室は上下方向の制振 床工法を探用している。長銀は12層の事務室等よりなっているが，

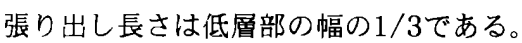

本プロジェクトの構造計画における大きな課題は 3 点ある。高層 部が基礎幅の約2.6倍とトップヘビーであることから地震時の転倒 モ一メントの処理，長大な跳出しを支える骨組計画，そしてその 跳ね出し部の地震時における上下振動の制御である。

転倒モ一メントに対しては「囲」字形の地中連続壁と本設地盤ア ンカーで処理した。骨組はメガストラクチャ一構法を採用し，上下 動に対しては跳ね出し部先端とその下の低層棟の間にオイルダン パーを設置して対処した。

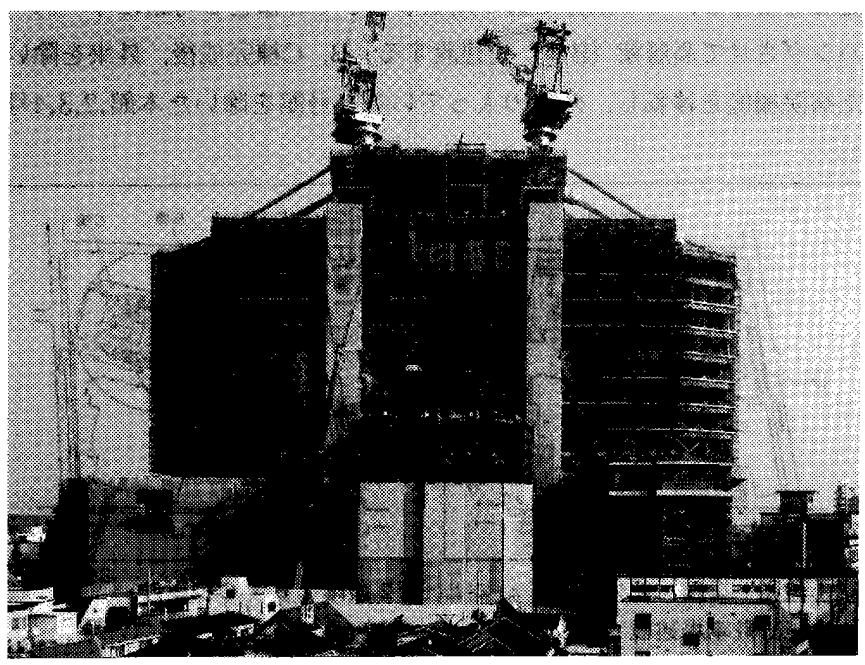

写真 1 建物全景（鉄骨工事完了時）

本報告は，特に基礎計画とオイルダンパーを用いた制振について 報告するものである。

\section{2. 部面樶要}

2.1 建物概要

建物 名称: 川崎市立川崎病院

建設場所：川崎市川崎区新川通12-1

建 筑 主 川崎市

設 計 監 理 川崎市まちづくり局・日本設計

*1 侏日本設計構造設計部 技術担当部長·工修

(下163-1329 新宿区西新宿6-5-1 新宿アイランドタワー29階)

*2 陎)日本設計構造設計部 工修

*3 龵日本設計構造設計群 統括部長・工博

*1 Senior Engineer, Nihon Sekkei Inc., Structural Engineering Dept., M. Eng.

*2 Engineer, NIHON SEKKEI Inc., Structural Engineering Dept., M. Eng.

*3 Director, NIHON SEKKEI Inc., Structural Engineering Div., Ph. D. 
施 工 者 竹中・前田・大日本・小川・吉忠建築 J V

教地面積 $19,813.00 \mathrm{~m}^{2}$

建築面積 $5,891.62 \mathrm{~m}^{2}$

延朱面積 $49.563 .72 \mathrm{~m}^{2}$

用途病院 (733床)

階 数 $\mathrm{A}$ 棟 (外来) 地上 4 階

$\mathrm{B}$ 棟（病棟）地下 1 階, 地上 15 階, 塔屋 2 階

$\mathrm{C}$ 棟 (検査 - 手術) 地上 5 階

最高部高さ $77.70 \mathrm{~m}$

軒高さ $65.67 \mathrm{~m}$

基準階高さ $4.35 \mathrm{~m}$ （下層部），4.05m（上層部）

基礎底深さ $10.30 \mathrm{~m}$

構 造種別 鉄骨造（A棟， B 棟地上）

鉄骨鉄筋コンクリート造（B 棟地下， C 棟）

基礎構造地中連続壁，場所打ちコンクリート搪底杭併用

（本設地盤アンカーを使用）

オ似タ゚パーの製作 カヤバ工業

外壁アルミパネル（B棟），P C a 版（A棟），

$\mathrm{PC}$ Ca版型枠鉄筋コンクリート造（C棟）

\section{2 改策手順}

改築の手順は図 1 に示すように，まず敬地の $1 / 4$ 部分にある既存 建屋を解体し，その部分に第 1 期工事としてC棟と 2 号館にオーバー ハングさせて高層棟（B棟）を建設する。 $\mathrm{B}, \mathrm{C}$ 棟完成後，外来を除い た病院機能を移転し，外来の入っている 1 号館を除いた本館,2,3,4号

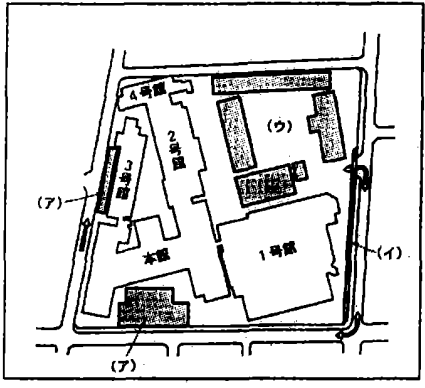

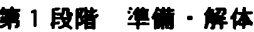

・自走式群車場建設 $(ア)$

- 一方通行道路拡幅 $(\uparrow)$

・看讙学院校舎, 学生尞, 体育館,

看境婦宿舎等解体 (ウ)

・設備機器・目己管盛り换元

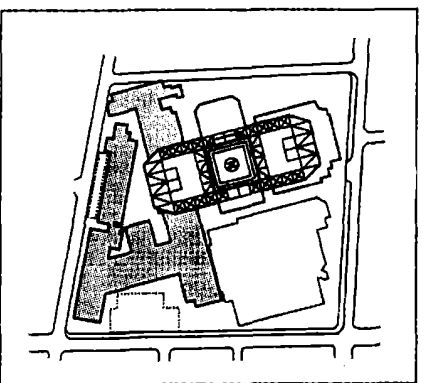

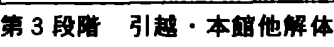

・外来以外の部門の移転

・トレーニング

・本館, $2,3,4$ 号館解体

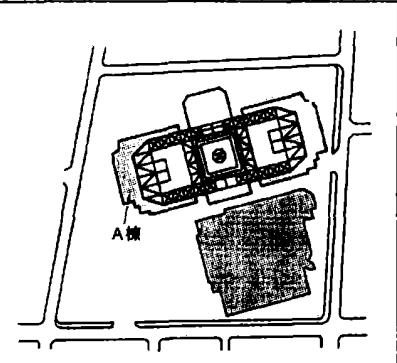

\section{第 4 段隌 A 椂理設}

- A 棟建設

- 1 号館解体

- 外構工事
図 1 改策手㮌
館を解体する。次に第 2 期工事として A 棟を建設し，最後に 1 号館を 解体するという手順である。この手順とすることによって，1 棟毎に 改築する方法に比べて半分の約 5 年で全ての改築工事が完了できる。

また，低層棟を病棟である高層棟とは切り放して作ってあるため， 将来の医療機器の発展に伴う改築は必要に応じて可能な計画となって いることも，建築計画上の副次的な特徴である。

\section{3. 情造設計のポイント}

この建物の特徵は，既存建屋の上空を利用した改築計画のため，高 層棟（B 棟）をT字形の立面形状にしたことにある。このような大き な跳ね出し部を有する建物の構造計画に当たっての大きな問題点は， 鉛直荷重を支える骨組形式，跳ね出し部先端の撓みと地震時の上下振 動による病室内の挙動，そして建物全体の転倒モーメントの処理であ る。これらの課題に対して，以下のような設計方針を立てた。

高層棟の骨組にはメガストラクチャー構法を採用する。図 2 に軸租 図，図 3 に伏図を示す。 4 本の柱を編み上げた組み柱（ヘラクレスポ スト）を， $36 \mathrm{~m} \times 36 \mathrm{~m}$ のコア部の四隅に配置する。このへラクレス ポストを心棒として，それから伸びる7階と15階のメガトラス及び 吊り材より構成されている。
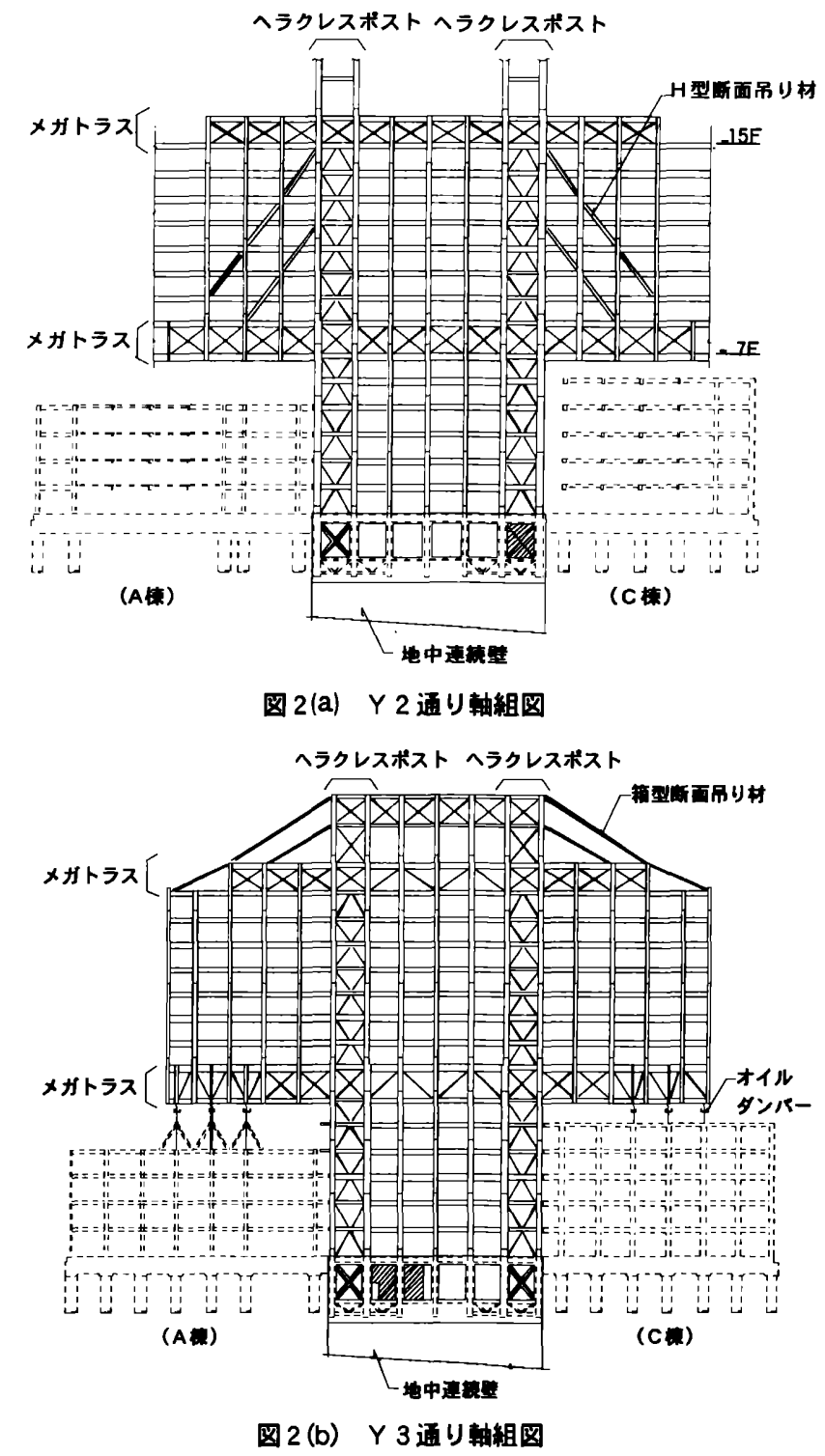
跳ね出し部先端部の撓みは $1 / 500$ 以下を目標とし，水平上下同時入 カのレベル 2地震時でもへラクレスポスト及び跳ね出し部の各構成部 材に塑性ヒンジが発生しないことを確かめる。

また地震時の上下動については，オイルダンパーを用いて制振す る。このとき頻度の高い地震に対してより大きな制振効果を発揮する ようにダンパーの性能を定める。

基礎幅に対して2.6倍というトップヘビーな形状のため，大きな転 倒モ一メントに抵抗する必要があり，基礎は大きな㴊性と耐力を必要 とする。四喁のヘラクレスポストを結ぶように「囲」字形の地中連続 壁と場所打ちコンクリート应底杭を併用し，かつ転倒に対する抵抗 モーメントを増すため本設地盤アンカーも採用する。設計クライテリ アとしてはレベル 1 地震に対しては浮き上がりが生じないようにし， レベル2に対しては十分な余裕を有するものとする。

\section{4. 基礎權造の設計 \\ 4.1 地盤概要}

当敷地は多摩川の河口に位置し，付近はかつて汇濫が繰り返され自 然堤防や背後湿地が認められるところである。敷地の地盤は，図 4 に 示すようにGL-25mまでは軟弱な砂層, シルト層であり, 層厚約 $2 \mathrm{~m}$ の $\mathrm{N}$ 値50以上の砂磁層の下はN 值50以上の土丹層が続く。

\section{2 設計方針}

地中連続壁は, 地震時のせん断力と全面主動土圧による面外二方向 曲げモ一メントを負担する耐震壁及び基礎杭としての性能を持つ二方 向版（一般認定工法）とする。

本設地盤アンカーは，地震時の転倒防止の目的で用いる。この目的 の本設地盤アンカ一は一般認定された工法が少なく，高層評定時には 工法を決めずに有効緊張力が120tf及び230tfと仮定して設計し，施工 者決定後に工法及び配置を決め基礎評定を受けることとした。

設計は，本設地盤アンカーの必要有効緊張力を試行錯誤法により求 めるという手順で進める。設計フローを図 5 に示す。

解析は，図6に示すようにB1階基礎梁以下の部分を対象に三次元 立体骨組としてモデル化し，以下の各段階ごとに静的解析を行う。た だし，レベル2地震時については地瞥の降伏や先端の浮き上がり等の 非線型を考虑して荷重増分解析を行う。
i ）アンカ一緊張直前
ii）アンカ一緊張直後
iii）躯体完了時（復水前）
iv）常時（復水後）
v) レベル 1 地震時
vi）レベル 2 地震時

このとき, 基礎梁は梁要素, 耐圧版と地中連続壁は平板シェル要素 とした三次元有限要素モデルとする。地盤の剛性としては周面摩擦バ ネ, 前面受動土圧バネ，先端の鈶直地盤バネを考虑し，各節点に集約 して取り付ける。場所打ち杭については，連続壁の水平剛性に比べて 小さく，かつ連続壁に近いため，水平剛性は無視して杭体の軸剛性と 先端地盤剛性より求めた鈶直支持バネのみを考慮する。

\section{3 地中連続壁}

地中連続壁は図 7 のに示すように, ヘラクレスポストより流れてく る過大な応力を分散させることができ，かつ大きな剛性と耐力を得る ために，ポスト直下を結ぶ「囲」字形に配置した。壁厚は1.5mで, 連続壁先端はGL- $27 \mathrm{~m}$ 以深の土丹層に $1 \mathrm{~m}$ 以上根入れできる深さの GL-28.5m 基本とし，特に引き抜き力の大きな部分（図 7 の斜線 部）はGL-33.0mとして, 引き抜き抵抗力（自重, 周面摩檫）を増大

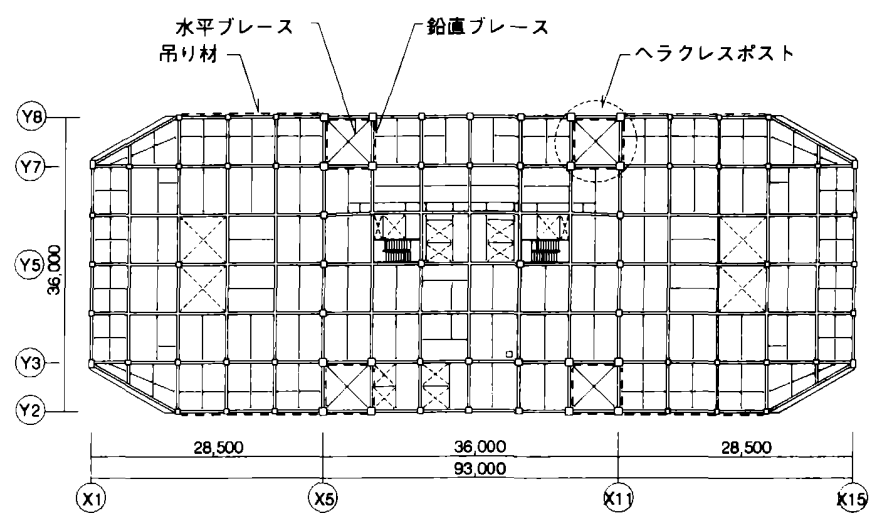

図 3 上屏部基準階伏図

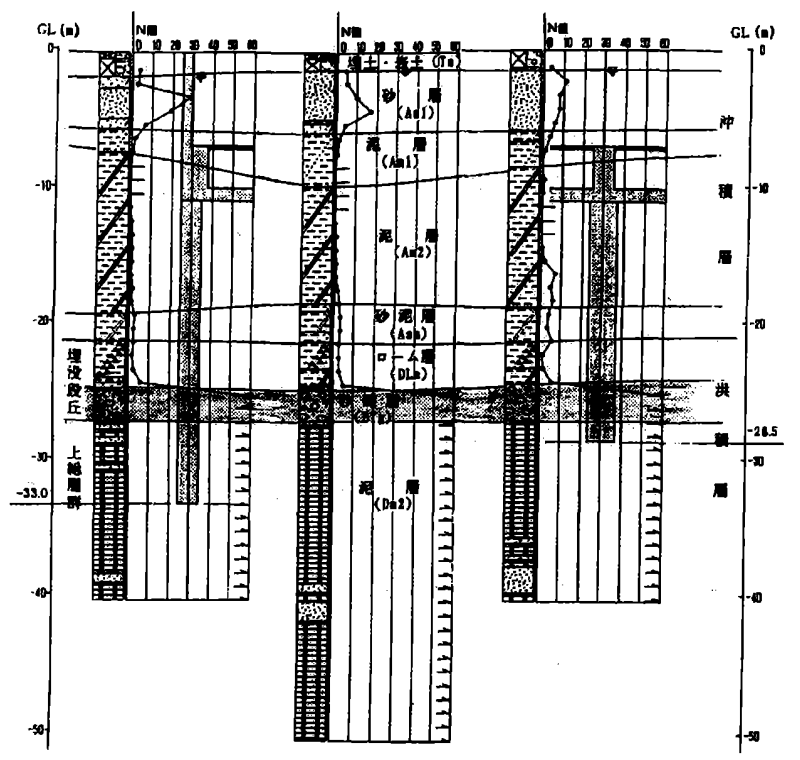

図 4 ボーリング柱状図

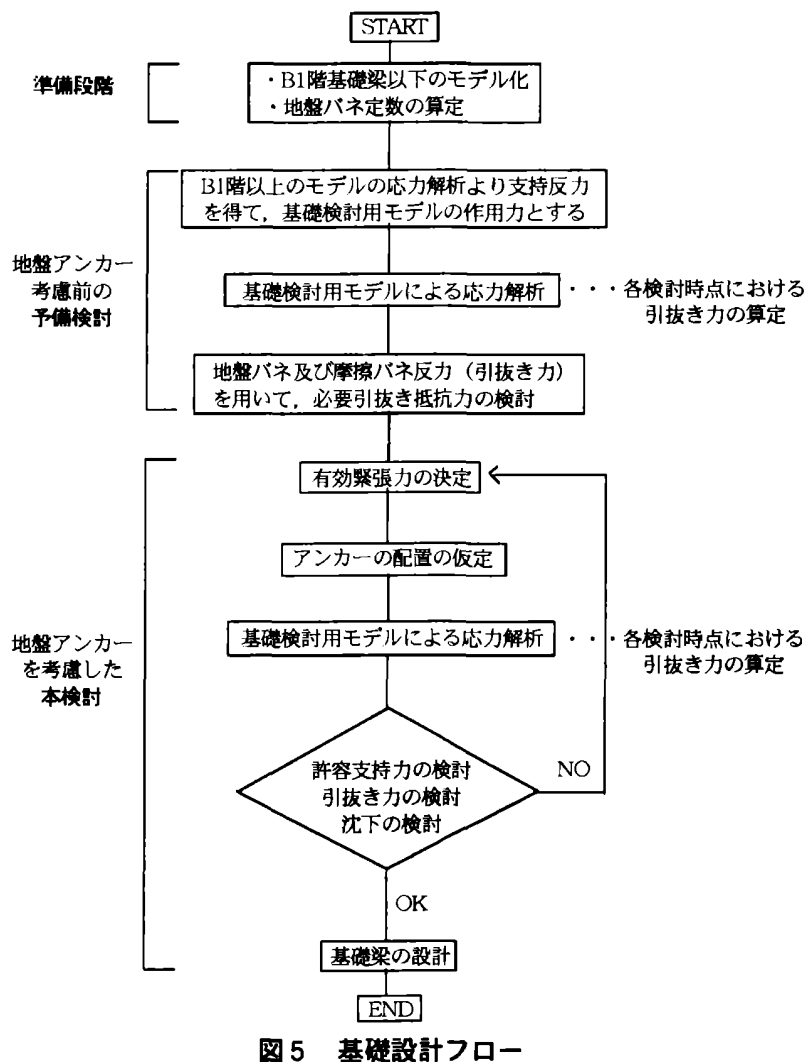

图 5 基礎設計フロー 
させる計画とした。

設計のクライテリアを表 1 に示す。解析結果を要的すると, 最大接 地圧は長期で $149 \mathrm{tf} / \mathrm{m}$ ，レベル 1 , レベル 2 地震時でそれぞれ260tf/ $\mathrm{m}^{2}, 378 \mathrm{tf} / \mathrm{m}$ と十分に許容值以下である。また浮き上がりはレベル 1 地震時では生じず, レベル 2 で部分的に発生するがその量は0.49cmと 小さく, 問題はない。施工上、ジョイントが必要になるが, その継手 性能は存在応力に対して十分な余力を持ち，かつパネルを大きくして その箇所数はできるだけ少なくした。

\section{4 本設地盤アンカー}

地盤アンカーは地中連続壁及び杭を貫通して（一部耐圧版より）土 丹層に定着させる。施工は連続壁及び杭の施工段階で鋼管を予め埋設 しておき，その後地上から掘削しアンカーをセットする。緊張端は基 礎梁上端とする。なおアンカーの配置は連続壁の中心としたため, 地 下耐震壁と干渉することになるが, 再緊張のための開口を耐震壁に設 けるよりも健全であると判断し，再緊張は行わないこととする。

施工者決定後, 地盤アンカーの工法はSTK永久アンカー(表 2)に し,アンカーの本数は, 各へラクレスポストの直下に 31 本（有効緊張 力約 4,200tf)、総計164本をX軸対象に配置した。X力向に対してア ンカーの抵抗モーメントは318,000tf·mとなり，レベル2地震時の転 倒モ一メント $688,000 \mathrm{tf} \cdot \mathrm{m}$ に対して46\%に相当する。

敷地内で行った引き抜き試験の結果，極限摩擦抵抗力は19.5 kgf/ c佂で, 定着体の長さは $5 \mathrm{~m}$ で十分であることが分かった。また, 余長 を $4 \mathrm{~m}$ 取ることにより杭先端部以深で $30^{\circ}$ と設定したせん断すべり面 の粘着力と土塊重量で十分な引き抜き耐力があり，破壊モードはアン カーの破断によることを確認した。

\section{5. 上部糤造の設計}

\section{1 設計方針}

全ての柱及びヘラクレスポストを含むメガストラクチャーと跳ね出 し部のフィーレンディールを構成する梁は, レベル2地震時でも弾性 範囲にあることを大前提とする他, 耐震設計のクライテリアは表 3 の 通りである。また長期荷重に対して跳ね出し部先端の撓みは $1 / 500$ 以 下を目標とする。

上部構造の解析は, 各節点が 6 自由度を持つ非剛床の三次元立体フ レームとして応力解析や荷重增分解析を行う。柱, 梁及び吊り材は三 次元梁要素, ブレースはトラス要素, スラブと地下の耐震壁は平面応 力要素に置換し，荷重は各節点に集中して作用させる。

また振動解析もこのモデルを用い，各節点（2155点）に質量を集 中させた立体フレーム弾塑性応答解析を行う。

\section{2 長期荷重時}

長期荷重時の応力は建て方順序によって大きく変わるが，設計段階 で詳細な建て方順序を特定することは難しい。このため解析上は全て 組み上がった骨組に荷重を作用させることとし，現場で極端な応力の 集中がない建て方をするという方針とした。

表 1 地中連続隼のクライテリア

\begin{tabular}{|c|c|c|c|}
\hline 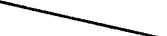 & 長 & レベル 1 & レベル 2 \\
\hline 応力 状 留 & 長期許容応力度以下 & 短期許容応力度以下 & 短期許容応力度以下 \\
\hline 碎容支持力 & $250 \mathrm{tf} / \mathrm{m}^{\prime}$ & $500 \mathrm{tf} / \mathrm{m}^{\mathrm{i}}$ & $750 \mathrm{tf} / \mathrm{m}^{\prime}$ \\
\hline 許容引き抜き力 & - & 自 & 自重＋周面摩擦力 \\
\hline 先端浮き上がり & - & 不 & 部分的なものは可 \\
\hline
\end{tabular}

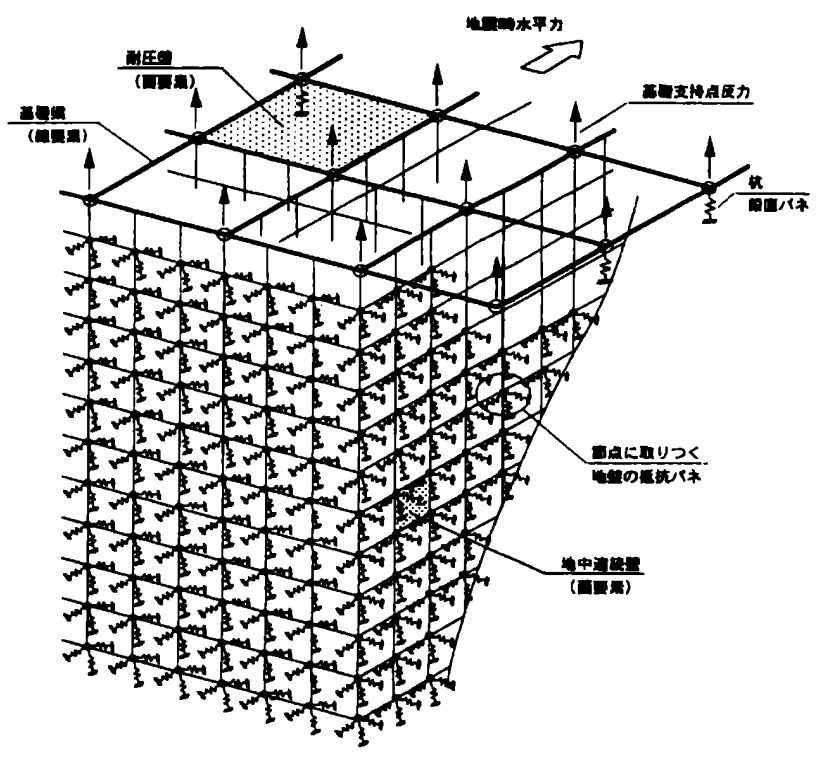

図 6 基䃈解析モデル

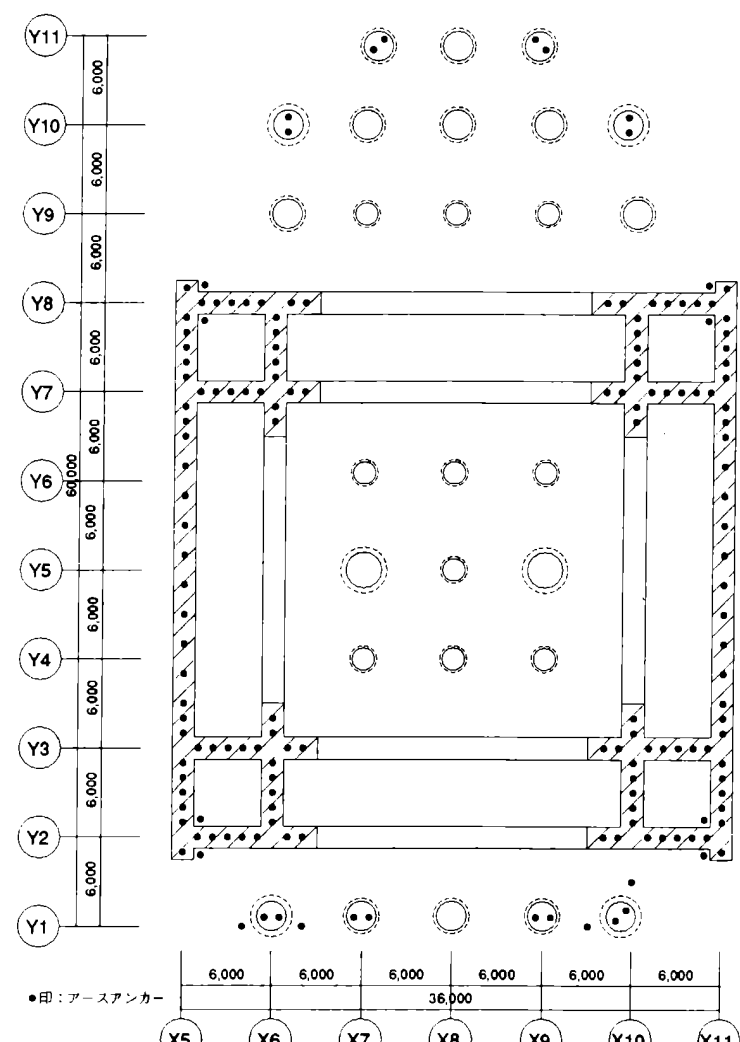

图 7 基磁伏図

表 2 STKアンカーの仕䓇

\begin{tabular}{|c|c|c|c|c|c|}
\hline \multirow{2}{*}{$\underset{\text { ア 呼 }}{\text { 名 }}$} & \multicolumn{2}{|c|}{ 許容引張力 (tf) } & \multirow{2}{*}{ 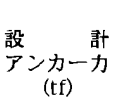 } & \multirow{2}{*}{$\begin{array}{l}\text { アンボンド } \\
\text { PCD線 }\end{array}$} & \multirow{2}{*}{$\begin{array}{c}\text { 定着体長さ } \\
\text { (m) }\end{array}$} \\
\hline & $\begin{array}{l}\text { 初 期 } \\
\text { 道人時 }\end{array}$ & $\begin{array}{l}\text { 定 着 } \\
\text { 完了時 }\end{array}$ & & & \\
\hline STK-200 & 170.0 & 161.6 & 135.0 & $4-\phi 21.8$ & 5.00 \\
\hline
\end{tabular}

表 3 耐設設計クライテリア

\begin{tabular}{|c|c|c|}
\hline & レ ベ ル 1 & レベル \\
\hline 入カレベル & 最大速度 $25 \mathrm{~cm} / \mathrm{s}$ & 最大速度 $50 \mathrm{~cm} / \mathrm{s}$ \\
\hline 忘力状態 & 全ての部材が短期許容态力度以下 & 累積部材望性事の最大㯈は10以下 \\
\hline 層間变形角 & 1/200以下 & 1/100以下 \\
\hline 周の望性事 & - & 2.0以下 \\
\hline
\end{tabular}


解析の結果，表 4 に示すように跳ね出し先端部の中央での撓みは $5.8 \mathrm{~cm}$ で，コア部に対する相対変形角は $1 / 590$ と初期の目標を満足し ている。また, メガトラス, 吊り材及びフィーレンディールの応力分

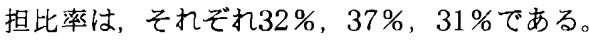

実際の建て方順序はここでは詳述しないが，仮設の吊り材を設けた り，元端から順次建てて行く方法により数力所の部材の補強で設計と ほぼ同等の忍力度とすることができた。また53m四のむくりを付けて 建て方を行い，想定した変位で建て方を終了した。

\section{3 地霞応答解析}

採用した地震波は表 5 の 4 波で, 入力方向はX，Y及び $45^{\circ} の 4$ 方向とした。X方向については, この中で応答が最も大きかった TAFTを用いて水平上下同時入力 $(X+Z)$ の解析も行った。

固有値解析で得られた骨組のX，Y及びZ方向の卓越モ一ドは，図 8 に示すように全体の 1 次, 3 次, 6 次に現れる。減衰定数は剛性比 例型と寸ると上下動に対して過大評価となる恐れがあるので，レー リ一型の内部粘性とし，1次（X力向 1 次）と 4 次（同2次）に対し て2\%になるように定めた。このときZ方向 1 次に対する減衰定数は $2.5 \%$ となる。

まず水平のみの入力に対して耐震設計クライテリアを満足するよう に部材を決定した。なお，地震時の跳称出し先端部の鈶直変位は表4 に示寸通りである。表中の地震荷重時は, $\mathrm{C}_{\mathrm{B}}=0.227$ に対する静的解 析の結果である。

$\mathrm{X}$ 方向の水平上下同時入力の $25 \mathrm{~cm} / \mathrm{s}$ レベル, $50 \mathrm{~cm} / \mathrm{s} レ$ ベルの忍答

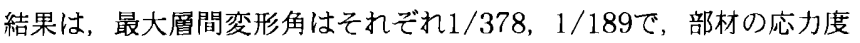
は $25 \mathrm{~cm} / \mathrm{s}$ レベルでは短期許容忍力度以下, $50 \mathrm{~cm} / \mathrm{s}$ レベルの部材の累 積塑性率は最大で1.07とほぼ弾性状態にあり，当初水平動のみに対し て決めた表 30 のイテリアを十分に満足している。

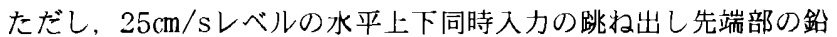
直方向の忍答値は, 最大加速度は $1 \mathrm{G}$ 超え, 最大変位も $10.8 \mathrm{~cm}$ と大 きい。この応答性状を改善するために, オイルダンパーを設置するこ ととした。

\section{6. オイルダンパーを用いた制振}

\section{1 減亭係数の䢖いによる比校検討}

跳ね出し先端部と低層棟の柱頭の間に, 速度比例型のオイルダン パーを片側 7 個ずつ設けた。低層棟の柱軸力に見合うように最大 200tf以下とする前提条件の中で，最も制振効果が得られるようなダ ンパーの減衰㛊数を求めるために, 減衰係数を $0,2,5,10 \mathrm{tf} \cdot \mathrm{s} / \mathrm{cm}$ 変 化させて水平上下同時入力の応答解析を行った。骨組モデルは前述の モデルのダンパーが取り付く節点にダッシュポットと低層棟の軸バネ を直列に追加した。

図 9 に減衰係数と最大応答加速度及び最大減衰力の関係を示す。

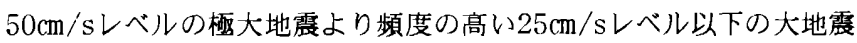
を主対象と考えると, 減衰力も過大とならず，最も制振効果がある減 衰係数は $5 \mathrm{tf} \cdot \mathrm{s} / \mathrm{cm}$ であることが分かる。

\section{2 オイルダンパーの性能}

以上の検討結果をもとにダンパーの性能は表 6 のように決めた。即

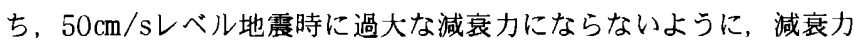
が180tfを超えると減衰係数が初期減衰係数の $10 \%$ に低下寸る仕様之 した。また図10に示すように，先端部の片側 5 個のダンパーは減衰
表 4 䠌ね出し部の鈶直变位 （cm）

\begin{tabular}{|c|c|c|c|c|}
\hline \multirow{2}{*}{$\begin{array}{c}\text { 位置 } \\
\text { (7 階) }\end{array}$} & \multicolumn{2}{|c|}{ 元端 $(\mathrm{X} 5, \mathrm{X} 11)$} & \multicolumn{2}{|c|}{ 先端 $(\mathrm{X} 1, \mathrm{X} 15)$} \\
\cline { 2 - 5 } & 端部 $(\mathrm{Y} 3, \mathrm{Y} 7)$ & 中央 $(\mathrm{Y} 5)$ & 端部 $(\mathrm{Y} 3, \mathrm{Y} 7)$ & 中央 $(\mathrm{Y} 5)$ \\
\hline 長期荷重時 & 0.92 & 1.07 & 5.29 & 5.77 \\
\hline 地展荷重時 & 1.16 & 0.77 & 8.35 & 8.27 \\
\hline レベル 1 & 0.9 & 0.6 & 8.5 & 8.6 \\
\hline レベル2 & 1.7 & 1.2 & 17.0 & 17.2 \\
\hline
\end{tabular}

表 5 入力地震波

\begin{tabular}{|c|c|c|c|c|}
\hline \multirow{2}{*}{ 方 向 } & \multirow{2}{*}{ 地 } & \multirow{2}{*}{ 名 } & \multicolumn{2}{|c|}{ 最大加速度 $\left(\mathrm{cm} / \mathrm{s}^{2}\right)$} \\
\hline & & & $25 \mathrm{~cm} / \mathrm{s} レ ヘ ゙ ル$ & $50 \mathrm{~cm} / \mathrm{s}$ レベル \\
\hline \multirow{4}{*}{ 水 平 } & EL CENTORO & NS & 255.4 & 510.8 \\
\hline & TAFT & EW & 248.4 & 496.8 \\
\hline & TOKYO 101 & NS & 242.5 & 484.9 \\
\hline & HACHINOHE & NS & 165.1 & 330.1 \\
\hline 上下 & TAFT & UD & 145.3 & 290.6 \\
\hline
\end{tabular}
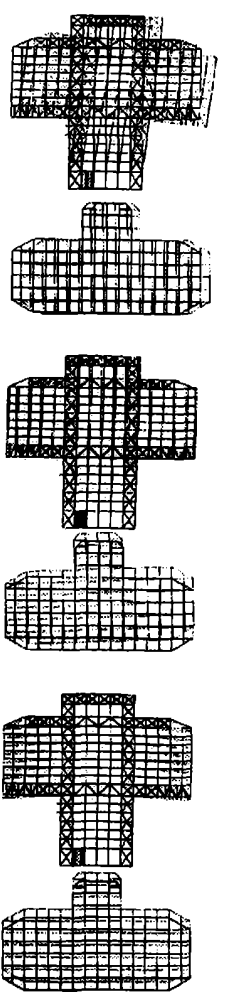

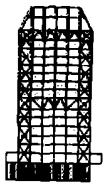

1 次

1.432 秒

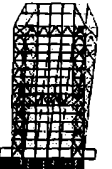

3次 1.411 秒

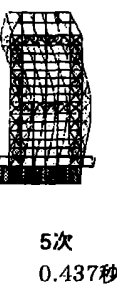

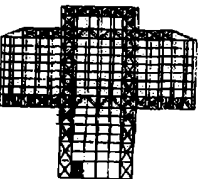
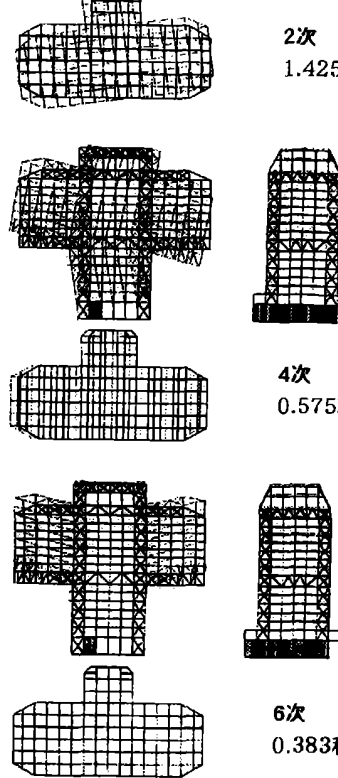

0.383 秒
図 8 固有値及び固有モード
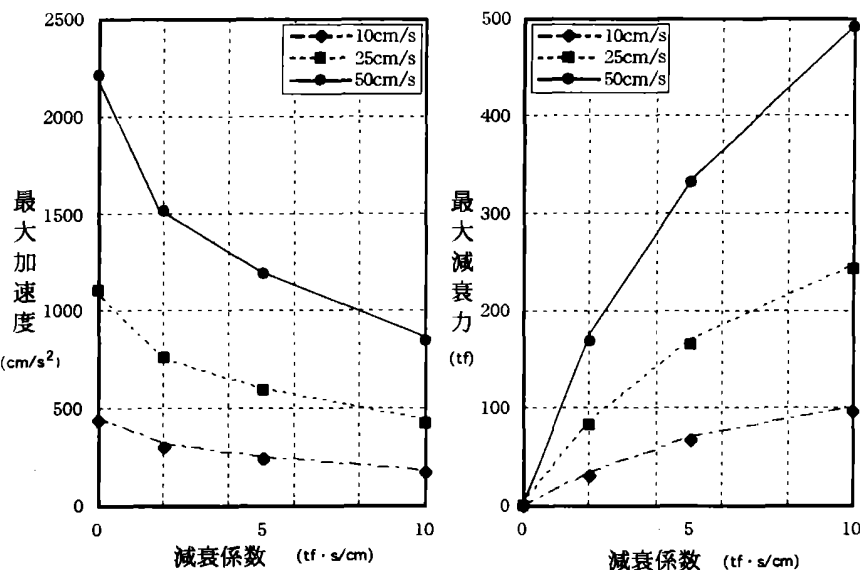

减衰係数 $(\mathrm{tf} \cdot \mathrm{s} / \mathrm{cm})$

図 9 減表係数の連いによる制振効果のケーススタディ 
係数が $5 \mathrm{tf} \cdot \mathrm{s} / \mathrm{cm}$, 内側のダンパーは応答速度が小さいのでより効果 が得られるように $10 \mathrm{tf} \cdot \mathrm{s} / \mathrm{cm}$ とた。ストロークは $50 \mathrm{~cm} / \mathrm{s} の$ 応答変位 の 2 倍に建て方精度等の逃げとして $5 \mathrm{~cm}$ 加えた值とした。

オイルダンパーの直径は $66 \mathrm{~cm}$ ，その取り付け長さ $210 \mathrm{~cm}$ で，外観 を写真2 に示す。最大減衰力 $200 \mathrm{tf}$ のオイルダンパーは過去に例がな い大きさであり，試験装置がなく減衰係数の切り替え部分の実物検 証はできなかったが，バルブ単体の試験により性能を確認した。

\section{3 制振効果}

$25 \mathrm{~cm} / \mathrm{s}$ レベルの水平上下同時入力時のダンパーの有り無しの比較 を図 11 に示す。また表 7 には最大値と平均的な大きさの比較のため に便宜的なものとして20秒間の rmsを示す。ダンパー無しに比べて

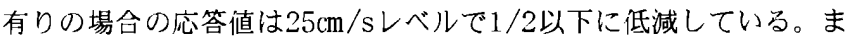
た図11(a)を見ると，上下の摇れだけでなく，水平の摇れも早く収ま ることが分かる。な㧍，50cm/sレベルでも制振効果は低下せず，1/ 2〜2/3程度に低減することを確認した。

また，A棟建設の約 1 年半の間ダンパーは片側のみの状態である が，両側にある場合の $85 \%$ 程度の制振勃果があることも確認した。

さらに振動台上に病室を再現して振動実験を行い，ベットや家具 の挙動を把握し，地震時の対応マニュアルの資料を得た。

\section{7. まとめ}

川崎病院の改筑プロジェクトを通して，既存建屋の上空にオ一 バーハングして建設するという特殊な建築計画を実現するための課 題に対して，構造計画の一つの解法を紹介した。

地中連続壁と本設地盤アンカーを併用することによって，長大な 跳ね出しを有するトップヘビィな建物の基礎として，十分な剛性と 強度を持たせることができた。

構造耐力上の安全性を確保することは最低条件であるが，地震時 の跳ね出し部の上下振動による入院患者の安全性の確保も考虑する 必要がある。このために，オイルダンパーを利用した制振を採用 し，上下振動を半減させることができた。

\section{謝辞}

本プロジェクトを設計するに当り，ご指導，ご協力いただいた川 崎市まちづくり局と健康福祉局, 川崎病院の皆様に感謝の意を表し ます。また基礎評定，鉄骨建て方計画等の検討において，ご協力い ただいた建築 JV，竹中工務店の構造設計部及び技術研究所の関係 者の皆様に感謝します。

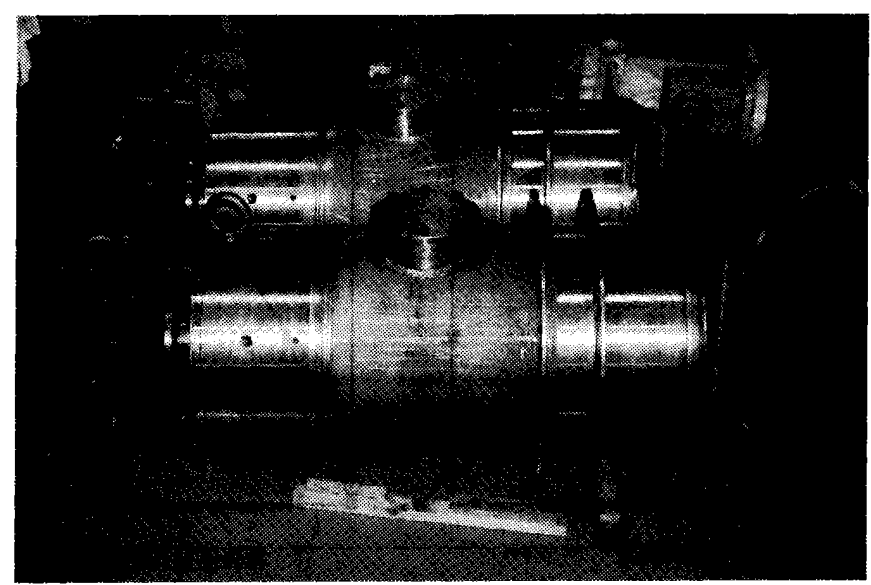

写真 2 オイルダンパー外覽
表 6 オイルダンパーの性能仕棣

\begin{tabular}{|c|c|c|}
\hline 娍衰係数 C & $5 \mathrm{tf} \cdot \mathrm{s} / \mathrm{cm}$ & $10 \mathrm{tf} \cdot \mathrm{s} / \mathrm{cm}$ \\
\hline 诚衰特性 & 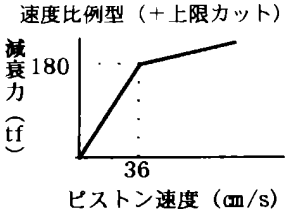 & 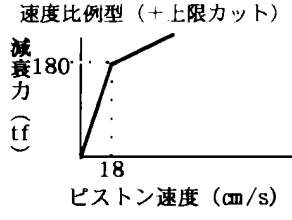 \\
\hline 用 & \multicolumn{2}{|c|}{ 両効き } \\
\hline 最大琙度力 $\mathrm{F}$ & \multicolumn{2}{|c|}{200 tf } \\
\hline 最大速度 & $125 \mathrm{~cm} / \mathrm{s}$ & $75 \mathrm{~cm} / \mathrm{s}$ \\
\hline ストローク & $\pm(20+5) \mathrm{cm}$ & $\pm(15+5) \mathrm{cm}$ \\
\hline 使用睘境 & \multicolumn{2}{|c|}{ 屋 外 } \\
\hline オイルの仕様 & 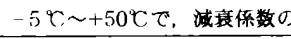 & が10\%以内となるオイルとする \\
\hline
\end{tabular}

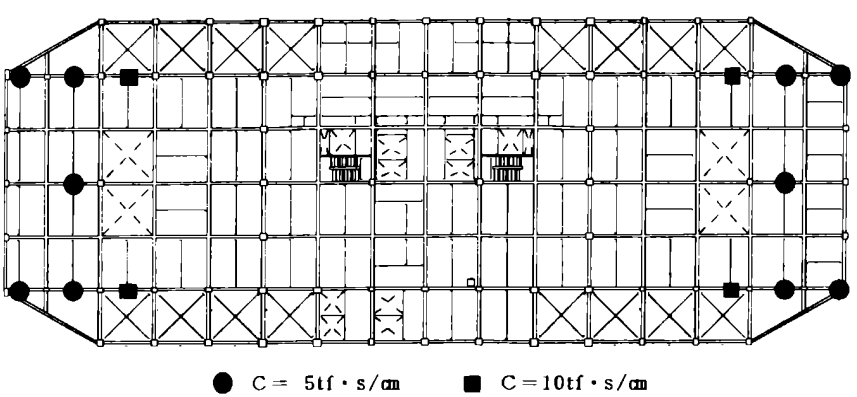

图10 オイルダンパーの取り付け位置

表 7 制振効果（上下方向）

\begin{tabular}{|c|c|c|c|c|c|c|c|}
\hline & \multirow{2}{*}{ ダン゚- } & 変 位 & $(\mathrm{cm})$ & 速 度 & $(\mathrm{cm} / \mathrm{s})$ & \multicolumn{2}{|c|}{ 加速度 $\left(\mathrm{cm} / \mathrm{s}^{2}\right)$} \\
\hline & & $\max$ & $\mathrm{rms}$ & $\max$ & $\mathrm{rms}$ & $\max$ & $\mathrm{rms}$ \\
\hline TAFT & 有 & 4.7 & 1.51 & 36.1 & 9.1 & 583. & 126. \\
\hline $25 \mathrm{~cm} / \mathrm{s}$ & 無 & 10.8 & 2.96 & 77.0 & 22.2 & 1179. & 294. \\
\hline レベル & 有，無 & 0.44 & 0.51 & 0.47 & 0.41 & 0.49 & 0.43 \\
\hline
\end{tabular}

(a) $\times$ 方向

变 位

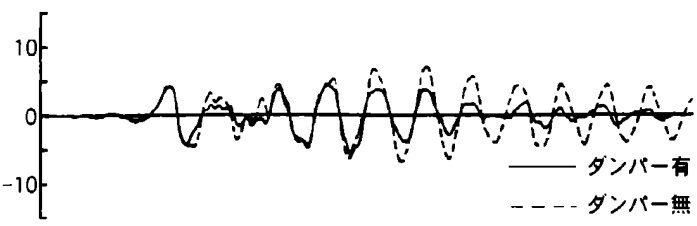

(b)上下方向

变 位

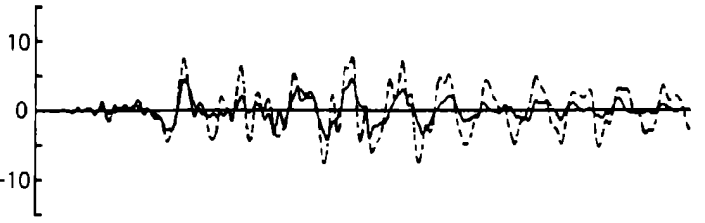

(c)上下方向
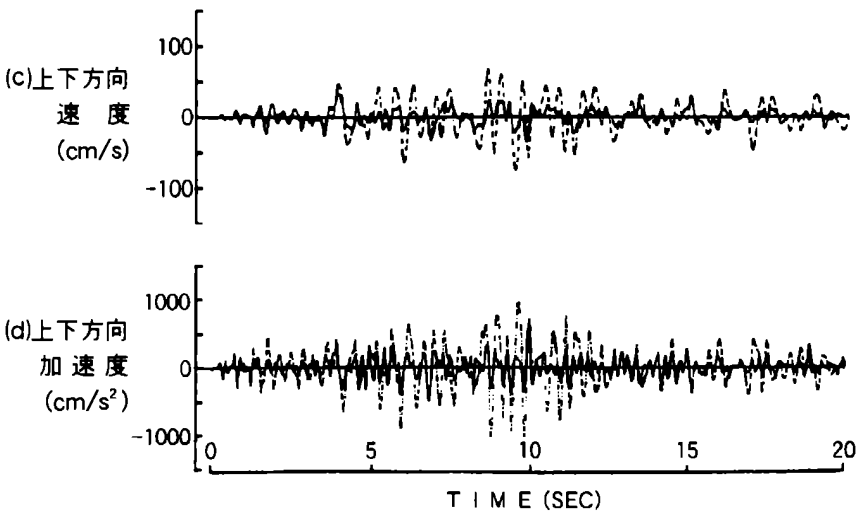

图1125cm/Sレペルの応答波形（ダンパーの有無）

[1998年 3 月 2 日原稿受理 1998年 7 月 8 日採用決定］ 